\title{
CONTRIBUTION OF GEOGRAPHIC INFORMATION SYSTEMS FOR THE MAPPING OF FLOODING FACTORS IN YAOUNDÉ: THE CASE STUDY OF MFOUNDI UPSTREAM WATERSHED
}

\author{
Zogning Moffo Maurice Olivier, Tsalefac Maurice, Ursu Adrian, \\ Iatu Corneliu
}

Keys words: GIS, flooding, human factors, natural factors, Yaoundé

\begin{abstract}
Built on a hilly relief, the city of Yaoundé is exposed to flooding since three decades. They caused human, material and environmental damages. Efficient management of this phenomenon by public authorities should go through a proper control of variables contributing to this hazard. Through various GIS applications based on multi temporal maps and primary data, we developed a detailed mapping of the main natural and human factors responsible for this phenomenon.
\end{abstract}

\section{Introduction}

Located between latitudes $3^{\circ} 42$ '39 ", $3^{\circ} 58^{\prime} 18^{\prime \prime}$ and longitude $11^{\circ} 25$ '11 ", $11^{\circ} 34^{\prime} 21^{\prime \prime}$ (Fig.1), the city of Yaoundé is exposed to many natural hazards such as mass movements, seismic risk and especially floods which are the most common and most harmful. Over the past three decades, 128 floods were recorded (ZOGNING Olivier, 2009). The floods have caused huge materials, environmental damages and above one hundred loss of life. The origins of these floods are shared between the natural elements of the milieu and the impact of mankind in the watershed. But to manage this complex phenomenon, governments require reliable spatial information that would facilitate decision making for effective intervention in the management of floodplains. The goal of this article is to highlight through Geographic Information Systems detailed mapping of the main floods factors. 


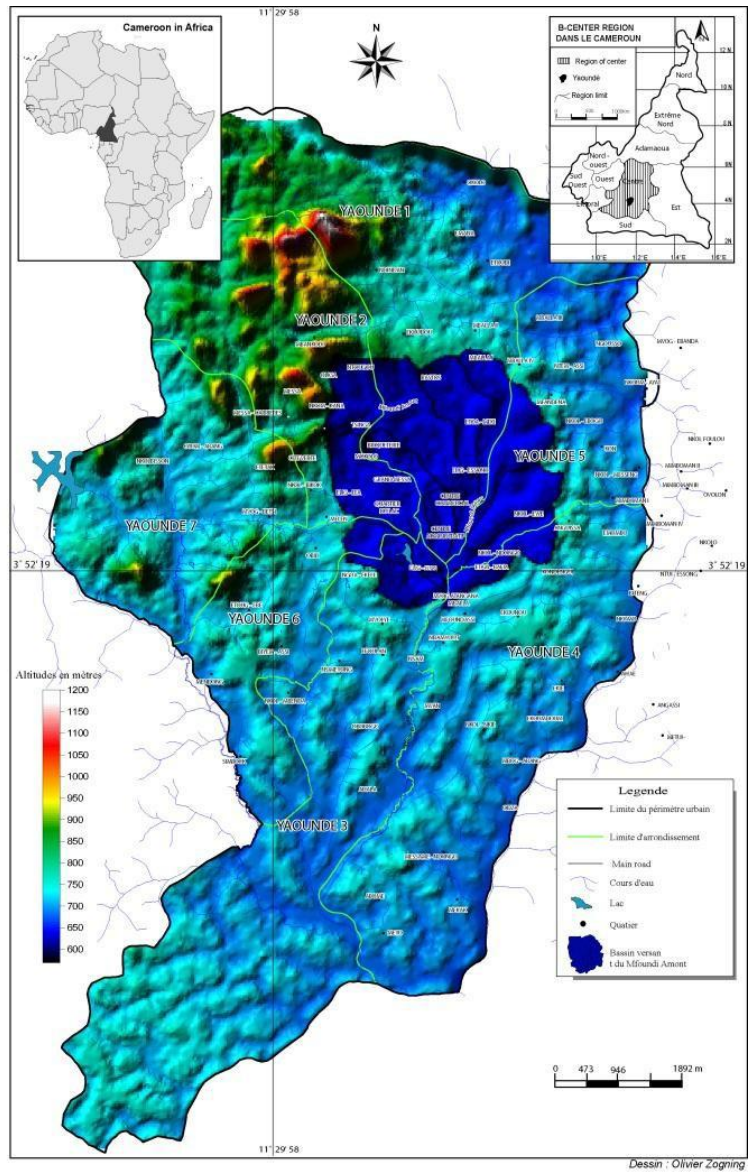

Figure 1: Location of the study area in the hilly site of Yaoundé

\section{Data and method}

\section{Data}

1.1.Rainfall data. The analysis of rainfall was based on the daily and monthly data derived from Monthly Climate Tables (MCT) of the National Direction of Meteorology of Douala. Treatment was facilitated by Excel that enabled for calculations and graphic projections. To get an idea of the general distribution of annual rainfall at the level Mfoundi upstream catchment, we relied on the map of annual isohyets Yaoundé developed by Kiet Srang in 1971. 
1.2. Frequency of flood. Two methods were used for the flooding acquisition data.

The first was exploiting the records of national daily newspapers (Cameroon tribune, Messenger etc.), reports of civil protection on risk events, theses and dissertations. These sources have been supplemented by broadcasting news, and field observation.

The second was done through a field investigation of 303 households in flood-prone areas through a GPS Garmin E-Trex. The surveys were carried out on the houses close to the river banks. Once the points were recorded, we used software MapSource to download waypoints before exporting them, to Excel to complete the information collected in the field. During the investigation, we attributed to each house a code ranging from A01 to H32 (Fig.2), we collected information such as the characteristics of the walls, the level of the foundation, year of construction, frequency of flood, duration and height of the floods, ethnicity, number of inhabitants, function, level of study, the method of risk management, etc.

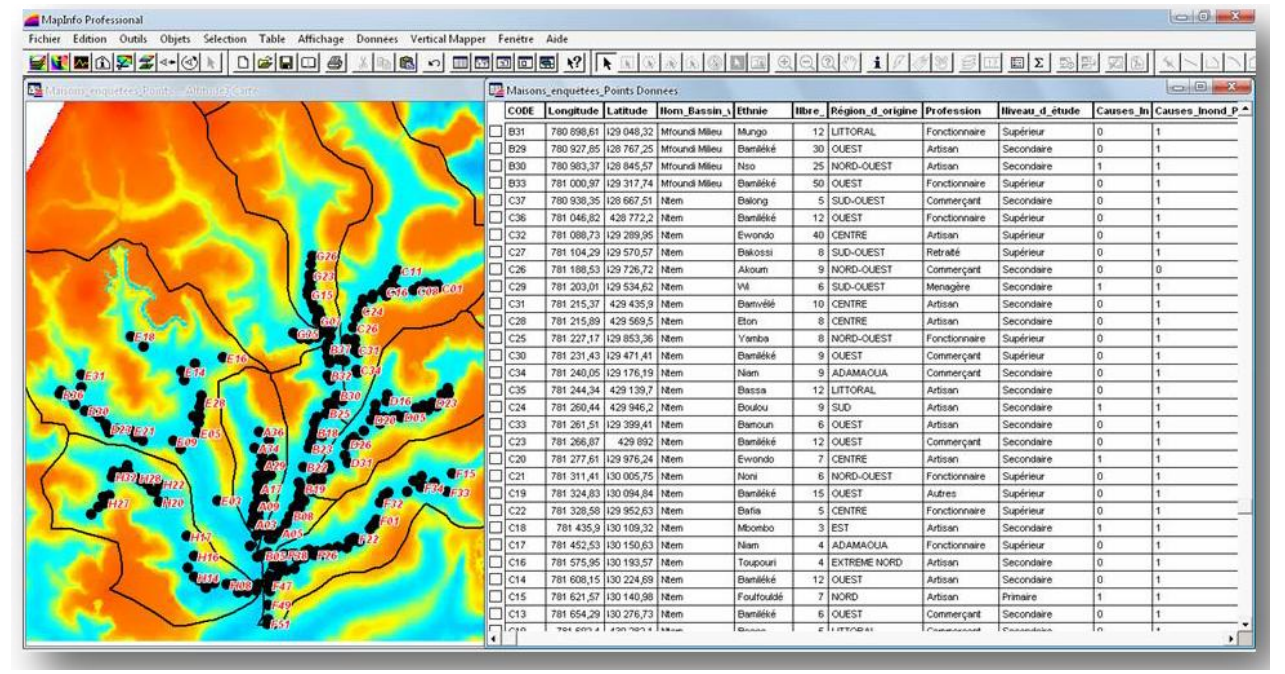

Figure 2: GPS surveys of the houses in the lowlands combined with their database

1.3. The cartographic data. Our study was based on several cartographic documents:

-The Yaoundé aerial photography of 1951 and 1980, respectively 1/10000 and $1 / 8000$,

- The isohyets map of Yaoundé isohyets elaborated by KIET SRANG in 
1970

We also benefited from the National Institute of Cartography, a database of Yaoundé. This database is derived from the aerial photography campaign conducted in 1995 by IGN France and updated in 2005. The database is organized into four categories. Elevation data include main and normal contour with an equidistance of 5 meters and 50000 spot heights. The data were georeferenced in the GAUSS KRUG projection system. Planimetry data include houses and roads. We also have hydrographic data and toponymy of the city. With Google Earth, we have been able to extract and mosaic satellite images of our watershed

\section{The method}

2.1. Treatment related to GIS. With MapInfo, ARCGIS and SURFER, we developed a series of Digital Elevation Model (DEM) to visualize the finest detail of relief of flood-prone areas. Several layers of information such as hydrography, vegetation and land use were overlaid on DEM to better understand urban sprawl in the Mfoundi upstream catchment. GIS facilitated the calculation of anthropogenic occupancy rate of the soil, to assess the waterproofing of watersheds. Generally, GIS allowed us to answer questions like: where are low flood risk areas located? What are their areas? Where are the most vulnerable populations at flood risks located? How many houses are there in these areas? What is the frequency of flooding in any given watershed, what is the maximum height of floods and what is the extent of damage caused? Etc.

2.2. Treatments of rainfall data, flood frequencies and field data. The data on rainfall and flooding frequencies were processed by the Excel spreadsheet, which enabled for sorting, calculations and graphic projections. However, to have a general idea of the distribution of annual rainfall at the level Mfoundi upstream catchment, we georeferenced the map of annual rainfall in Mapinfo to facilitate the overlaying of additional information in the same system. Then we digitized isohyets through the Mfoundi watershed. With Vertical Mapper, polylines (isohyets) were converted into points to facilitate the extraction of coordinates and annual rainfall representing the $\mathrm{Z}$ value. These points have been exported to Surfer and interpolated with an emphasis on "Kriging" algorithm. As for the field data, they were stripped directly through MapInfo through a template mask modeled on our survey sheet. The data were stored in its spreadsheet and exported to Excel and SPSS. 


\section{Results and analysis}

3. Status report on floods evolution and damage occurred

From 1980 to 2008, 128 floods were recorded through documentaries and media sources. A correlation effort between flooding and associated rainfall was made when it was possible. By examining the evolution of flood frequencies, we can observe three significant situations (Figure 3). The first concerns the décennia1980-1991 where there is an average of 04 floods with peaks of 6 cases in 1981 and 1984. The 1984 flood is probably related to its high rainfall which reached $2028.5 \mathrm{~mm}$ in 177 rainy days. The second observation concerns the time slot from 1992 to 1995 where there is a gap due to lack of information. The third case is the oscillating period between 1996 and 2008 characterized by a net growth of floods with an average 06 cases per year and peak of 12 floods in 2000, 10 in 2007, 08 in 2002, 07 in 2003. Unlike what one might think, the rainfall examination showed a real decrease while the frequencies, of flooding have increased. This assumes implicitly the presence of another factor aggravating the possibility of occurrence of the phenomenon. It is the anthropogenic factor that acts through urbanization and its consequences at the scale of watersheds in the city.

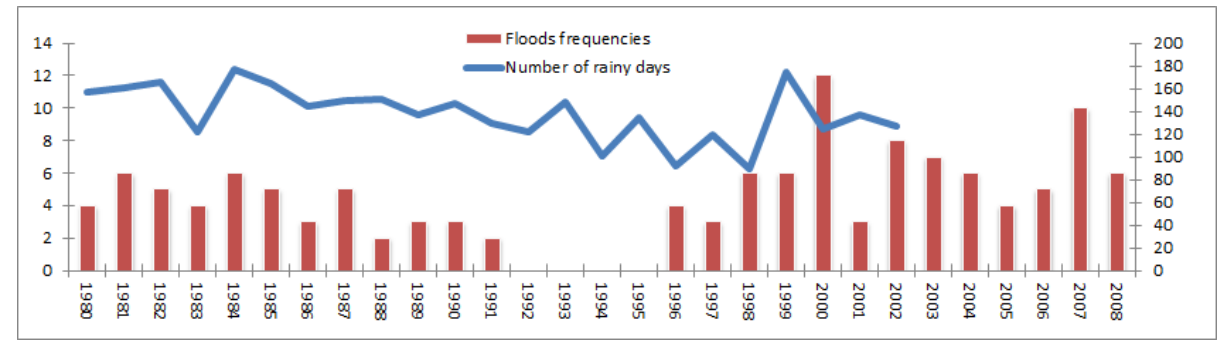

Figure 3: Annual frequencies, of flooding and number of rainy days from 1980 to 2008

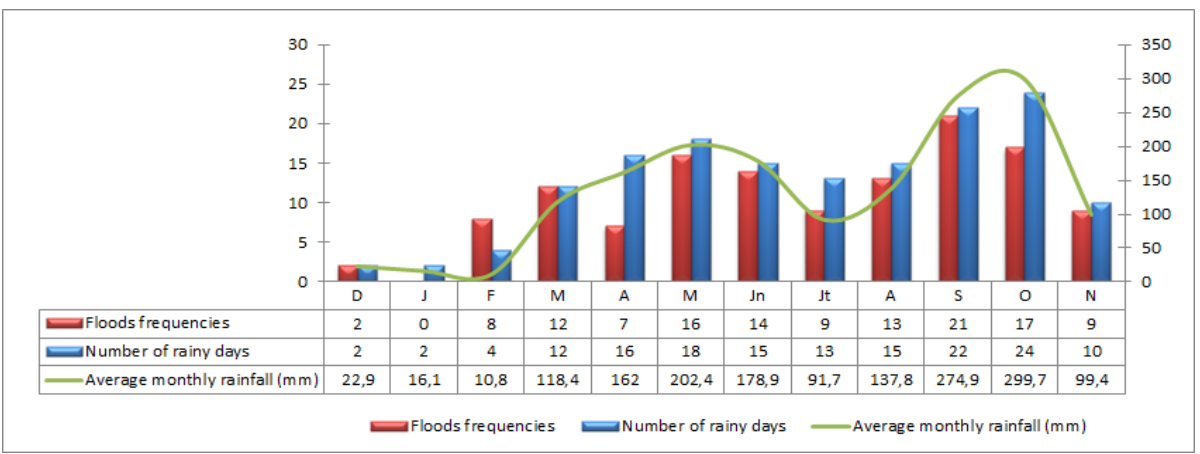

Figure 4: flood frequencies, number of rainy days and monthly average rainfall of Yaoundé 
The monthly grouping of floods shows a strong link between rainfall and periods of flooding (Figure 4). Two periods of flooding modeled on the two main rainy seasons emerge. The first is from February to June with an average of 11.4 per month where the flood peak is found in May and June (16 and 14 cases) and the minimum in February. However, it should be noted that it was in February 2000 and 2003 that took place some of the most fearsome floods of the past 10 years. The second period covers the end of August, September and October with an average of 17 floods. The month with high prevalence of flooding here is September with 21 cases and an average of 22 rainy days.
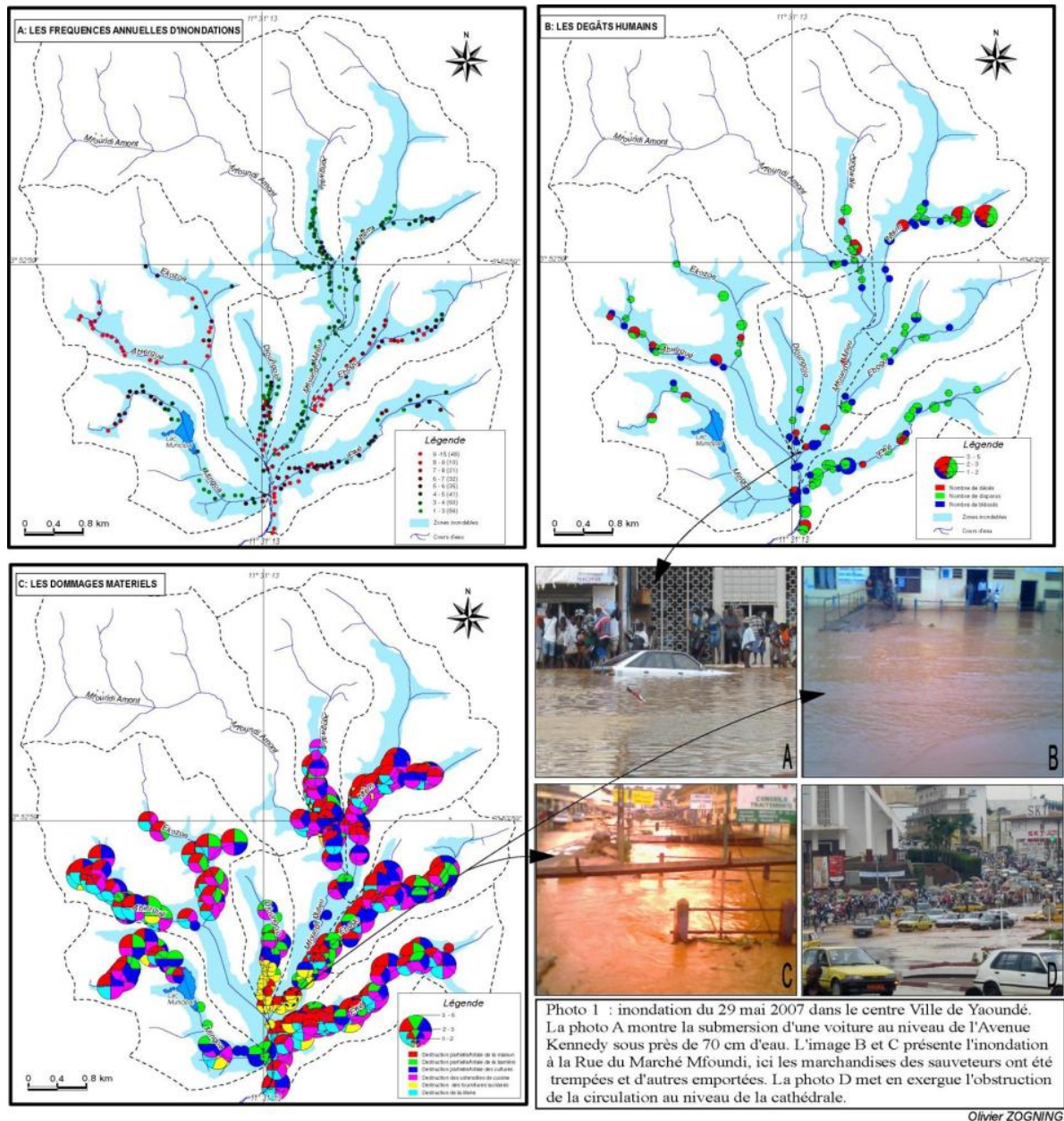

Figure 5: flood frequencies, human and material damage in the Mfoundi upstream watershed 
Overall, the floods have caused enormous material damage (destruction and burial of houses and computer equipment and photographic print in the city center) environmental (destruction of riparian crops, roads and vehicles as shown in (photo 1B) growth of waterborne diseases and malaria in the lowlands) and especially around a hundred deaths. Indeed, the frequency of flooding and the damage caused can be further maximized when examined closely the information collected in the field. Concerning the flood frequency, 19\% year experience 3-4 floods annually, $18.48 \% \quad 1-3$ and $15.84 \%$ 9-15 flooding (5A). Regarding human damage, the collected sample reported 96 wounded 48 missing persons and 33 deaths. Material damage is also enormous. 199 households or $65.67 \%$ complained of partial or total destruction of their homes. However, this damage is unequally distributed in the sub watershed as presented in Figure 5C.

\section{Cartography of natural and human factors generating floods}

4.1. The natural factors. They are many and can be classified in two main groups; passive agents (shape of the watershed topography, slope) and the active agents (rainfall, hydrography).

4.1.1. Passive agents. These are the physical environment elements that act indirectly or insidiously into the process of flooding. The shape of the watershed is the first indicator. According to Jost (1987) quoted by Michel Tchotsoua (1993), the size and shape of a watershed strongly influence the behavior of water received, collected and evacuated. If the other physical and human conditions are similar, the time of concentration of rainwater collected in a short massif watershed will be much shorter and will cause more rapidly flooding than in a watershed of elongated shape. Using GIS software, we were able to extract some topographic parameters of Mfoundi upstream catchment in general and its sub- watersheds in particular. These parameters were passed under the scrutiny of some indices used to express the geometric characters of watersheds such as compactness coefficient of Gravelius, the length of the equivalent Rectangle, the Horton Elongation Index. The results obtained are shown in Table 1.

On Table 1 we see that the Mfoundi upstream watershed covers an area of $37.54 \mathrm{~km}^{2}$ with a perimeter of $27.72 \mathrm{~km}$. The Gravelius compactness coefficient that is frequently used to express the compactness of watershed is 1.26 for the Mfoundi upstream watershed. As compared to the result obtained by Michel Tchotsoua (1993), which was 1.68 for the entire watershed, the Mfoundi upstream watershed seems more compact and thus promotes a rapid runoff concentration in the river. Indeed, the Mfoundi upstream watershed is almost square, the difference between the maximum length and the maximum width is $0.76 \mathrm{Km}$. 
This promotes rapid growth of the water flow towards the outlet and often causes dramatic flooding in case of heavy rain.

Table 1: some geometric parameters of Mfoundi upstream catchment

\begin{tabular}{|c|c|c|c|}
\hline & Designation & Formula & Results \\
\hline $\operatorname{Area}\left(\mathrm{Km}^{2}\right)$ & S & & 37,54 \\
\hline $\operatorname{Perimeter}(\mathrm{Km})$ & $\mathrm{P}$ & & 27,72 \\
\hline compactness coefficient of Gravelius & $\mathrm{Cg}$ & $0,28 x P / \sqrt{ } S$ & 1,26 \\
\hline Length of the equivalent Rectangle & $\mathrm{Le}$ & $C g \sqrt{ } S / 1,12\left[1+\sqrt{ } 1\left(1.12^{2} / 1,82\right)\right]$ & 10,78 \\
\hline Maximum length of the watershed (Km & $\mathrm{Lm}$ & & 7,32 \\
\hline Maximum width of the watershed (Km) & $\operatorname{lm}$ & & 9,56 \\
\hline Elongation index of Horton & $\mathrm{Hg}$ & $\mathrm{Lm} / \mathrm{lm}$ & 1,11 \\
\hline Total length of rivers $(\mathrm{Km})$ & $\Sigma$ Lce & & 54,39 \\
\hline Drainage density & Dd & $\Sigma$ Lce/S & 1,45 \\
\hline
\end{tabular}

The relief of the city of Yaoundé is part of natural factors exposing it to frequent flooding. Yaoundé is called "city of seven hills" because of its hilly terrain dotted with valleys. According to Assako. J.R. (1997); valleys occupy $20 \%$ of the total area of the city, which is equivalent to an area of 3600 ha. As is the entire relief of the city, the Mfoundi upstream watershed is scattered with moist valleys separated by long interfluves with convex and concave slopes. Thus, the general shape of the relief is like a hand whose fingers are the northwest mountains at the north of the city and downtown palm of hand which is the convergence of multiple valleys (Benoit Mougoué,1985) (Fig. 6C).

The watershed of Mfoundi has an average altitude of $777.5 \mathrm{~m}$ with and amplitude of $215 \mathrm{~m}$. The overall altitude decreases from North to South. This arrangement of the relief has an impact on the river system flowing in the same direction. Runoff therefore, are forcing very quickly at the confluence of the Central Post Office. The most vulnerable altitudes to flooding are ranged between 660 to $720 \mathrm{~m}$ as shown in Figure 6 D. 

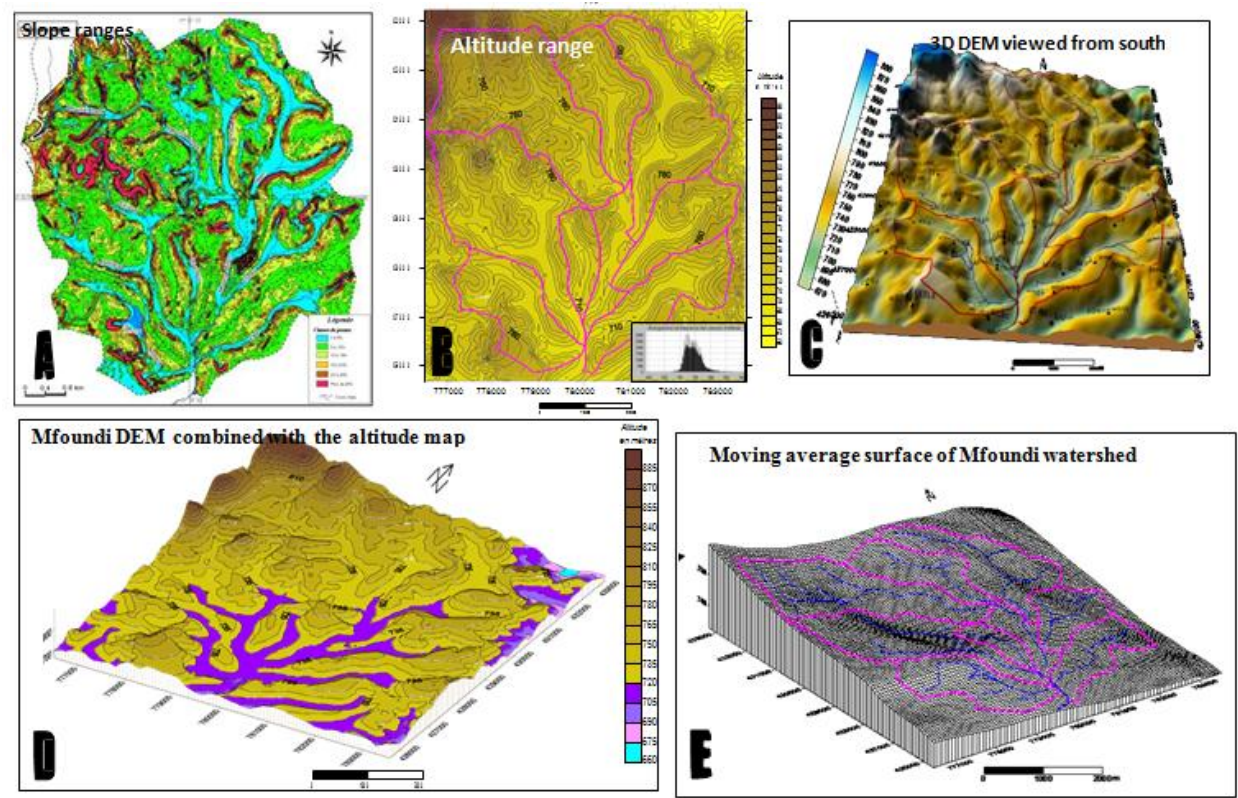

Figure 6: relief, slopes, and moving average surface Mfoundi upstream watershed

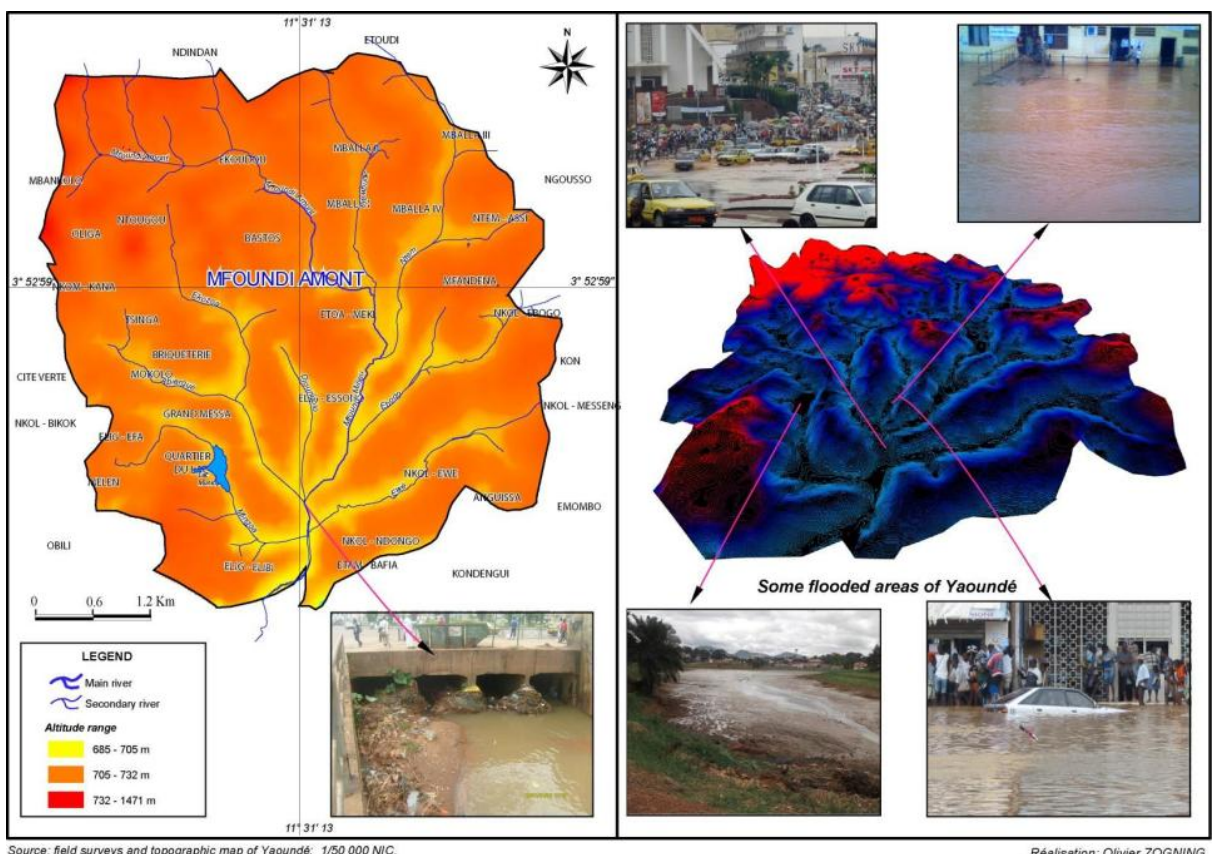

Figure 7: altitude map of Yaoundé and some flooded areas 
The slope is also a passive factor of flooding. It accelerates runoff when it is high and favors the concentration of water when it is low. On the Figure 6A, we see that the most susceptible class to flooding slope is between 0 and $5 \%$. It occupies $23.96 \%$ of the watershed, an area of 1204.78 ha. By eliminating the slopes of interfluves of this category, an area of $4.87 \mathrm{~km}^{2}$ is obtained only for the marsh valleys. At the Central Post Office, for example, the slope is very low and even close to zero $(0$ to $1.5 \%)$. It is mainly here that the slope influences flooding by water retention effect. Indeed, from the $20^{\text {th }}$ May Boulevard to Kennedy Avenue through the roundabout of the Central Post Office, floods are recurrent and often last more than two hours before the overall flood recession (Photo 2). Certainly other parameters such as the width of the valley and obstruction of drainage structures influence this phenomenon, but ultimately weak slopes of riverbed and channels more slow the runoff. This is similar to the Street of Mfoundi market at the National Investment Company (NIC).
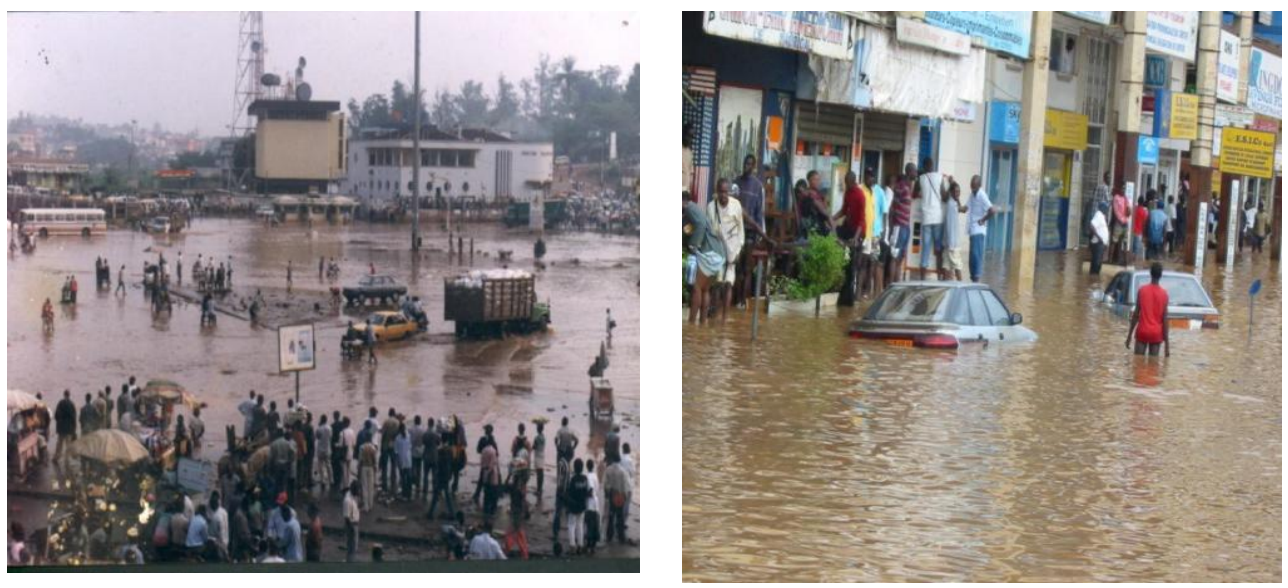

Photo 2: flooding of 29 May 2007 at the Central Post Office (A) and at Kennedy Avenue (B)

4.1.2. Active agents. This involves the elements of the milieu that directly influence floods such as hydrography and precipitation. Firstly the hydrographic network of Mfoundi upstream watershed is favorable to flooding because of its structure and density. Indeed, the total length of the river of Mfoundi upstream watershed is 54.39 kilometers. By establishing a relationship between the total length of rivers and catchment area, we obtain a drainage density of 1.45 , indicating that the dendritic river of this watershed is fairly provided. According to the nomenclature of Horton, we identified 38 sections of rivers of rank 1,20 sections of rank 2, 11 sections of rank 3 and 2 sections of rank 4 (Fig.8). 
The rivers of rank 3 are abundant in the Mfoundi upstream watershed and in the south of the basin. At the city center, all the rivers of rank 2 and 3 join to form the rank 4 below the roundabout of the Central Post Office. This is evident with the transversal increase of the channel of the main river which is 7 meters at Mfoundi Street and 9 meters after the confluence (ZOGNING Olivier, 2005). After this confluence, the river Mfoundi comes out behind the ENEO Agency and still joins river Mingoa and Ewe where they cause severe floods.

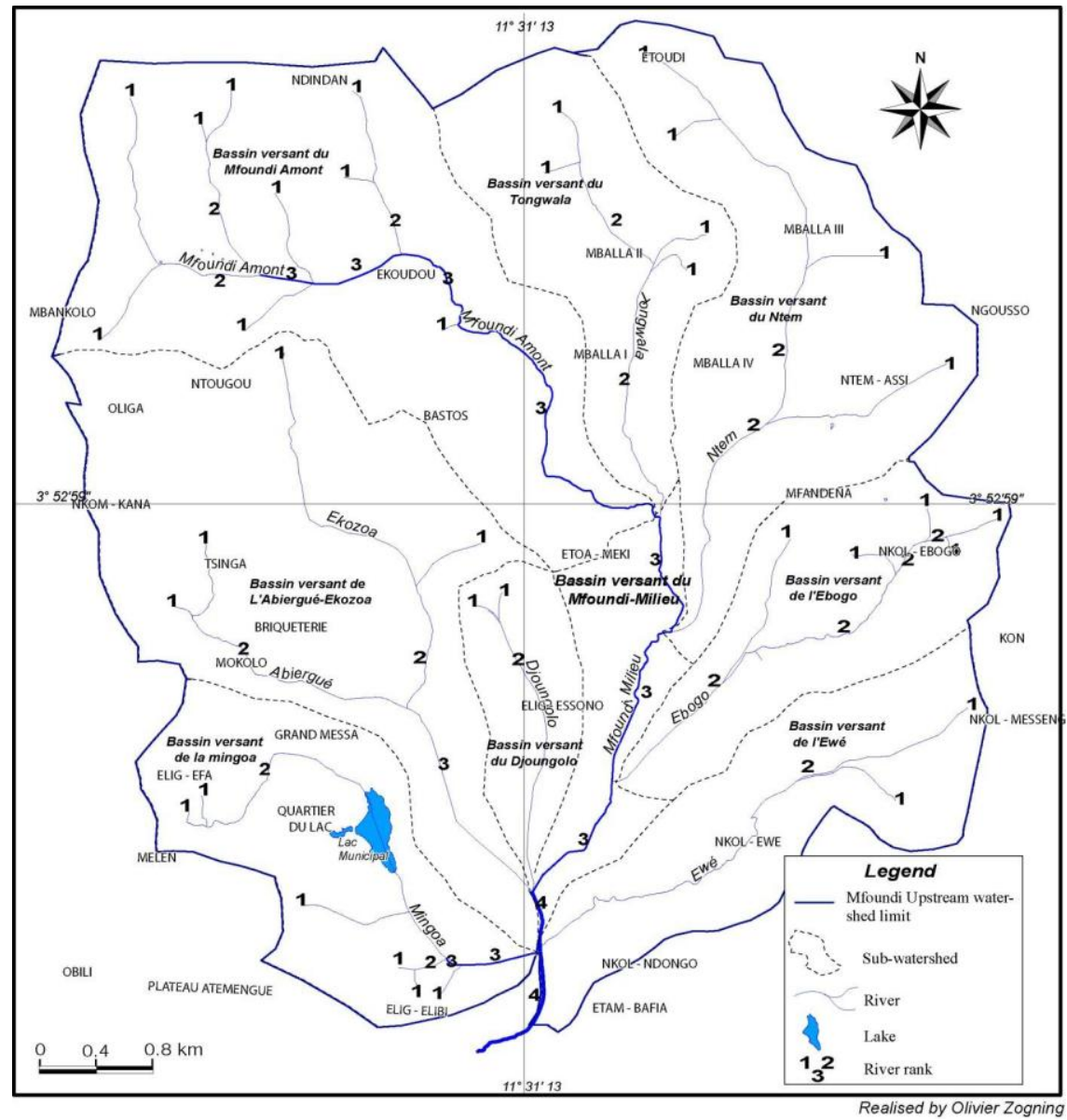

Figure.8: the hydrographic network of Mfoundi upstream and its rivers ranks

After hydrography, we have rainfall that is without any doubt the trigger factor of this phenomenon. In fact, it is moreover the main factor because we cannot have flood without water. A correlation test between flooding and 
rainfall amount revealed that some catastrophic floods were caused by long heavy rains. This is the case of the flood of 26 August 1986 which took away the bridge over Mfoundi River at the Voirie Municipal after a downpour of 87.0 $\mathrm{mm}$. We also have in mind the recent flooding of 15 November 2007 at the Mfoundi Market Street, the Avenue Kennedy at Olézoa and Abattoir Market caused by a rain of $55 \mathrm{~mm}$. However, when considering the annual distribution of rainfall, we find that it is unequally distributed throughout the city and the Mfoundi watershed. To better appreciate these inequalities, we modeled under GIS the map of Yaoundé isohyets 1971. As the climate of
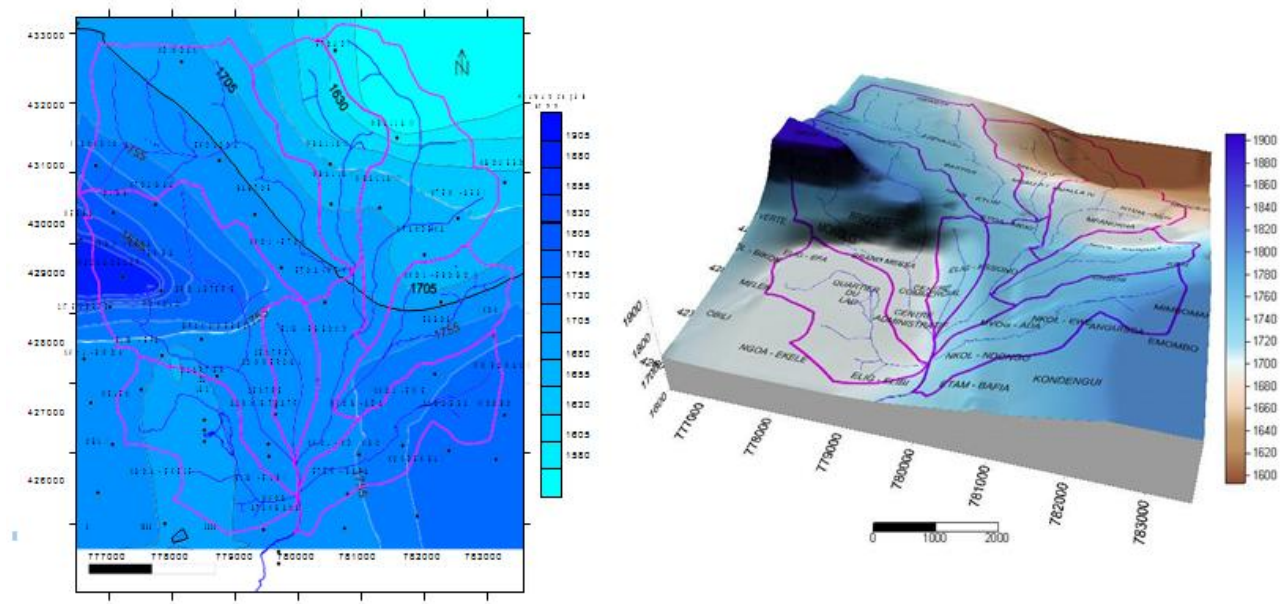

Figure 9: annual distribution of rainfall in the Mfoundi upstream watershed

Yaoundé has not changed radically after thirty years, this map developed by Kiet Srang remains the only support to assess the rainfall distribution in the capital as well as the watershed of Mfoundi. This is due of the abundance of stations that allowed its realization. Although it does not account the entire phenomenon, it nevertheless remains a powerful tool for assessing the distribution of rainfall. In general, rainfall is abundant on the axis Northwest Southeast while it shows a considerable drop in the Northeast and the Southwest (Fig. 9). By overlaying the map of the watersheds of Mfoundi and its hydrography on the rainfall map, we see that the catchment area of the AbierguéEkozoa is the rainiest in its northern part; it is crossed in the northwest by isohyets ranged between $1700 \mathrm{~mm}$ and $1900 \mathrm{~mm}$. The abundance of rainfall in the watershed has a close link with the relief that is also emphasized at the same place. This area of heavy precipitation corresponds to altitude slices of 850 to $880 \mathrm{~m}$ where we find the Mount Messa and the surrounding summits at the 
Palais des Congrès, Ntougou etc. In this watershed floods are frequent. The city center that is in shelter position receives only rain remains. This is even more pronounced that the Nkolbisson station accumulates $2050 \mathrm{~mm}$ against $1700 \mathrm{~mm}$ per year for the administrative center and $1550 \mathrm{~mm}$ for the North East of the city where one finds the watershed of Ntem and Mballa I, Mballa III, and Etoudi neighborhoods.

Although the elements of the physical environment of the city predispose it to flooding, it must still be noted that the unplanned urbanization of its site and its corollaries played a lead role in the increase of flood frequency.

\subsubsection{Human factors}

2.2.2. The evolution of the population and its impact on urban sprawl. Born in a small Ewondo village located in the heart of the southern Cameroonian rainforest, Yaoundé has evolved with 22 huts in 1895 to some 61,881 structures in 1987 (SDAU 2001). Between 1976 and 1997 the population of Yaoundé has almost tripled from 313,705 to $1,121,786$. This rise is explained by the high rate of growth that was 7\% after independence (Bopda A. 1995). In 1999, the population was estimated at 1.2 million by the French Cooperation with a growth rate of $4 \%$. After the census of 1987, the natural growth of the population oscillates between 28 and 33\% with 67\% of immigration (Tchotsoua, 1993). Immigration in the city is caused by the rural exodus, unemployment and poverty in general. In 2002 it was amounted to 1,487,551 and 1,881,876 in 2005.

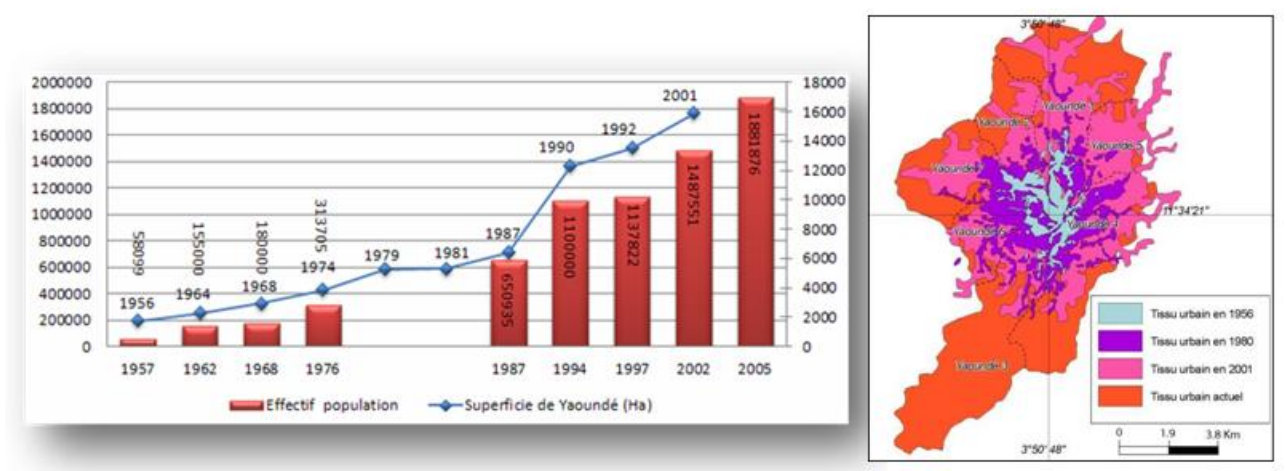

Figure 10: Population growth and evolution of urban sprawl in Yaoundé

This rapid population growth has had a significant impact on the spatial dynamic of the city and concomitantly on the invasion of risk zones such as steep slope areas and especially the marsh lowland. By combining the graph of population growth with the graph of evolution of the urban task, we find that the 
two phenomena have evolved in parallel (Fig. 10). Demography has promoted increased consumption of space especially during the 1980s. Indeed, between 1987 and 2002 the population grew by 836,616 people during the same period, 9500 ha of space have been consumed. It is in early 1980 that floods have taken a decisive turn. In fact, $35.31 \%$ of the riparian populations said they had experienced their first floods in the years 1980-1990.

The consequences of this urbanization are visible through the growth of impermeable surfaces (buildings and asphalt) throughout the Mfoundi upstream watershed and especially in flood areas. To better understand the impact of man on the genesis of this phenomenon, we have carried out a diachronic analysis of the houses, asphalt and vegetation.

2.2.2.2. Dynamics of built in the Mfoundi upstream watershed. The occupancy rate or soil sealing by homes passed successively from $6.21 \%$ in 1951 to $17.27 \%$ in 1980 and reaches $21.70 \%$ in 2005 . The surface waterproofed by the houses was 233,2 ha in

1951, 648.14 in 1980 and 814.59 ha in 2005 (Fig. 11 A). This corresponds to 10,543 homes in 1951, 29149 in 1980 and 38260 in 2005. However, these values are far from being identical when considering the dynamics of land use by sub watershed.

2.2.2.3. Diachronic analysis of buildings in flood zones. Flood areas occupy $25.86 \%$ of the total area of the watershed of Mfoundi or 970.96 ha. The evolution of constructions in these areas has been relatively rapid. In 1951, 2,254 houses were built in the valleys of Mfoundi, which corresponded to a flood built area of 58.13 ha or $5.99 \%$ of the coverage rate of these areas (Fig.10 B). In 1980, the number of houses passes 7,230 for a habitable area of 158.66 ha and a coverage rate of flood zones of around 16.34\%. In 2005, the demographic explosion increases the number of Houses at 10,118 is for a populated area of 158.66 ha and a waterproofing rate of $21.93 \%$. Considering to 3 the number of people living in a household, we can multiply this minimum value by the number of dwellings and estimate the population at risk of flooding. On this basis, the population at risk in 2005 was 30,354 inhabitants 

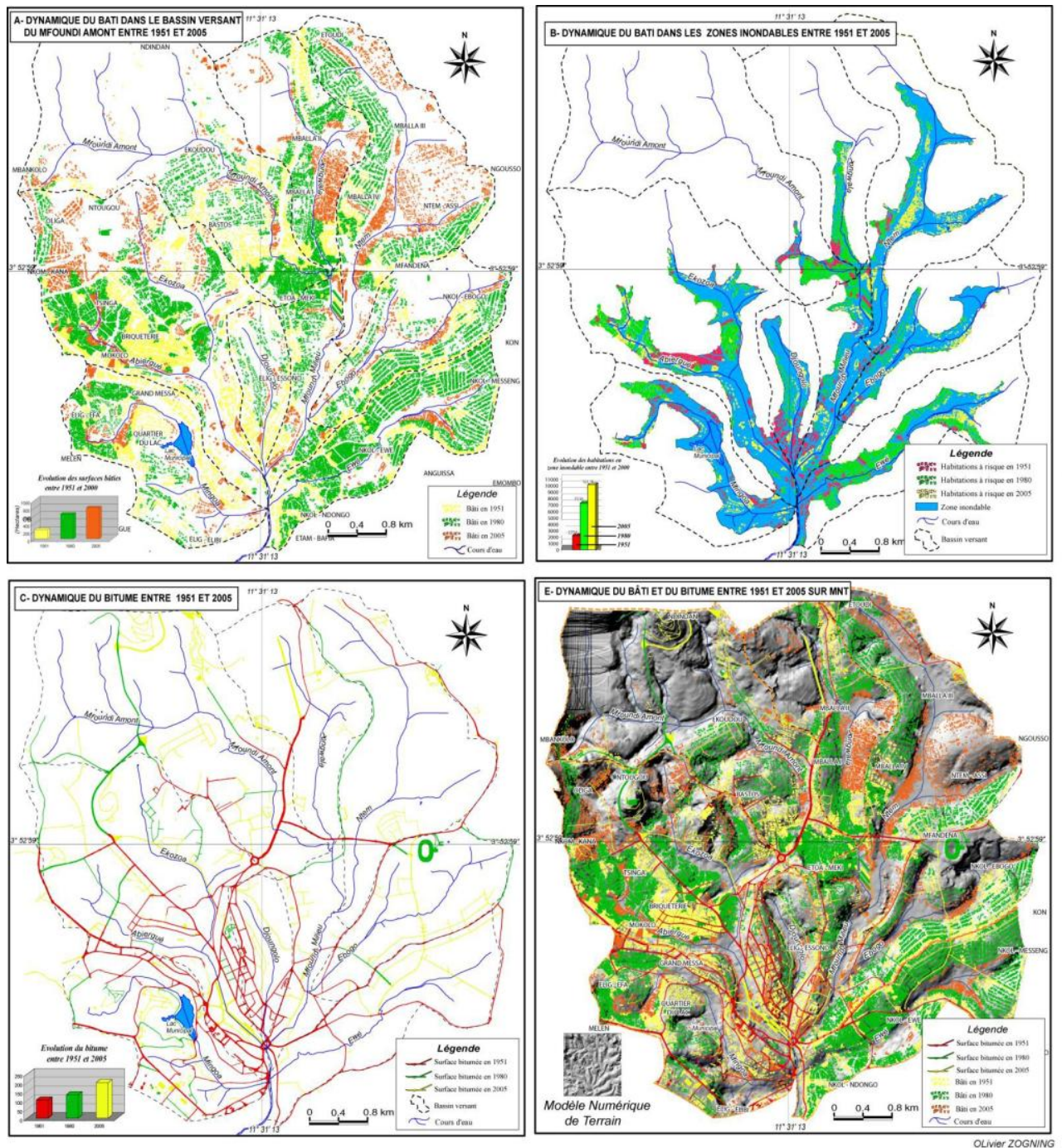

Figure 11: Evolution of houses and asphalt in the Mfoundi upstream watershed from 1951 to 2005

2.2.2.4. Evolution of paved surfaces and vulnerability of storm drainage and water evacuation structures. The urbanization of the watershed by the paved road network has contributed more to the recovery of the soil and the increased of runoff toward the flood prone areas. In 1951, the rate of waterproofing of Mfoundi watershed by asphalt was $2.73 \%$, which was equivalent to 102.33 ha 
of asphalt surface. In 1980 it will increase to 132.78 ha and 201.2 ha in 2005 , with a waterproofing rate of $5.3 \%$. The length of paved road network increased from $505 \mathrm{~km}$ in 1978 to $696 \mathrm{~km}$ in 1998 (Mougoué Benoît, 1998). During road construction in the Mfoundi upstream watershed several water evacuation structures (culverts, gutters, and pipe and bridges) were built on the edges and of rivers. With urbanization, these structures have aged and are now very vulnerable. All these weaknesses demonstrate the part of government responsibilities in the genesis of floods. Logically proper construction of water evacuation structures and ongoing maintenance should allow long term easy drainage of rain water, but it is the reverse, rather they contain runoff and increase water towards floodplains, causing the blockage of traffic. The burial of River Ekozoa under the boulevard of $20^{\text {th }}$ May until the confluence of Mfoundi in 1981 is a good illustration. (Figure 12)

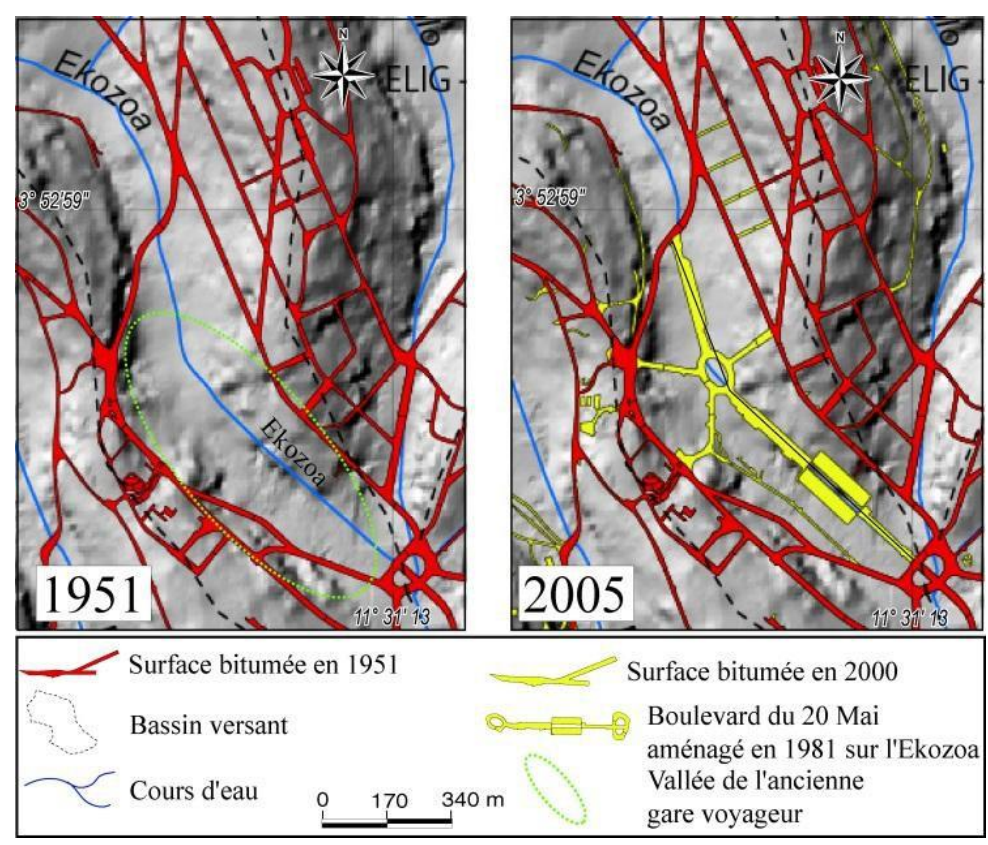

Figure 12: Evolution of the construction of 20th May Boulevard on MNT between 1951 and 2005 Overall, waterproofing rates of the basin by buildings and asphalt has increased dramatically: $8.93 \%$ in $1951,20.80 \%$ in 1980 and $27.06 \%$ in 2005 . This corresponds to surfaces waterproofed of 335.53 ha and 780.92 ha $1,015.79$ ha $\left(10.15 \mathrm{~km}^{2}\right)$ in 2005 . This soil changes at the expense of the vegetation cover which has increased flooding in all sub watersheds of Mfoundi upstream. 
2.2.2.5. Regression of vegetation cover in the Mfoundi upstream watershed and flooding. By comparing the data of decimated forest on the scale of the city with those of flood frequencies demonstrated above, we find that the period of deforestation between 1881-1992-2001 rhymes with decades of strong flood frequencies. During these two decades, nearly 10,600 ha of forest have been decimated, aggravating thereby the runoff, slope erosion and rapid sedimentation of rivers that obstruct the drainage structures. In the Mfoundi upstream watershed, change in vegetation cover has come at the place of urbanization in the watershed. We assessed the vegetation cover at 2934 ha in 1951. At the time, the urbanization of the city was more concentrated in the west and south, the coverage rate of soil by vegetation was very high $78.16 \%$. The Ntem basin which today includes the neighborhoods Mbala III, Mbala I Etoudi, etc. was completely covered with forest. Between 1951 and 1980, the coverage rate had been divided by 2 that is $33.73 \%$ for 1266 ha (Fig. 13). In 29 years of urbanization, 1668 ha of forest were razed. All sub watersheds of Mfoundi were stripped of their vegetation cover to more than 60\%. In 2005, deforestation reached its peak with only 223.8 ha of vegetation covering the watershed, representing a coverage rate of $6 \%$.
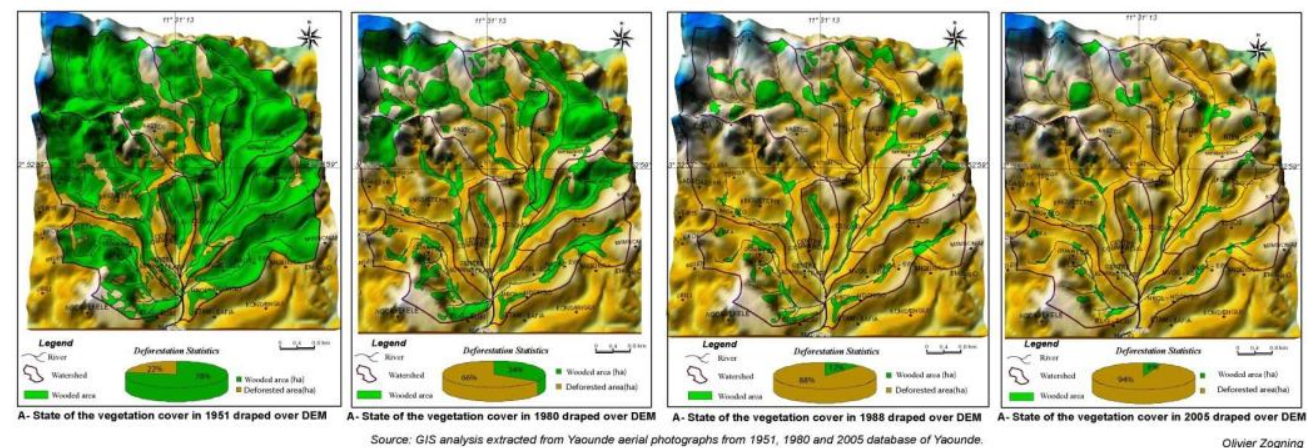

Figure 13: regression of vegetation cover of Mfoundi watershed between 1951 and 2005

\section{Conclusions}

The purpose of this article was to highlight the main natural and human factors responsible for the increase in flooding in the Mfoundi upstream watershed and through GIS. With this tool, we tried to apprehend the different variables of flood risk and to assess the frequency of the phenomenon and damages caused. By integrating various map data (multi date aerial photo, isohyets map) and in situ data collected in flood prone areas, we proceeded by overlays and modeling of the 
factors responsible for this phenomenon. It appears at first that the physical milieu of the Mfoundi upstream watershed is prone to flooding, due to the shape of the watershed (almost square), low slopes of valleys (0-5\%), a dense hydrographic network and abundant rainfall of $1600 \mathrm{~mm}$ which is the trigger for the process. Secondly, the detailed mapping of urban sprawl has revealed that mankind was acting as an amplifier of flooding. Indeed, a link was found between urban growth and increased frequency of flooding, there were in the 1980s, 46 floods against 61 for the years 2000 to 2008. In parallel, the city area tripled between 1981 and 2001 , from 5,300 to 15,900 ha. However due to the complexity of this phenomenon we were not able to quantify to their fair values the weight exerted by natural and anthropogenic factors on the process of flooding. This is due to the fact that the various factors combined, are linked or take turns to cause exceptional floods. Effective management of flood risks should go through a joint awareness of governments and local populations.

\section{References}

Assako Assako R. J., (1997), Yaoundé : elements pour un SIG urbain. Rapport de stage d'Excellence, AUPELF-UREF, université de Fribourg, Suisse 67 p.

Bopda Athanase, (1986), La dynamique de l'espace urbain à yaoundé. Reconstruction et expansion post coloniale du bâti, Thèse de $3^{\text {ème }}$ cycle, université de Yaoundé.

Mougoué. B., (1985), "La municipalité et les sites inconstructibles à Yaoundé " Cameroon Urban Review, $\mathrm{N}^{\circ} 1$ pp 38-40.

Tchotsoua, M. et Bonvallot J., (2001), Les risques morphodynamiques à Yaoundé. In Yaoundé, une grande métropole au Seuil du troisième millénaire. Les classiques africains, pp 193-200.

Thouret J.C., D'Ercole R., (1994), Les phénomènes naturels créateurs de dommages et menaces: diagnostic, inventaires et typologie, revue de Géographie Alpine $\mathrm{N}^{\circ} 4$ tome LXXXII.

KIET S., (1972), Hydrologie d'un BV de zone urbaine : le BV du Mfoundi à Yaoundé, ORSTOM 26p. Zogning Moffo. M. O., (2005), Risques d'inondations à Yaoundé : le cas de la zone confluence du Mfoundi au centre-ville et des quartiers péricentraux bassin versant de l'Ekozoa. Mémoire de maîtrise, Université de Yaoundé I, 112p.

Zogning Moffo. M.O., (2009), Apport des Systèmes d'Information Géographique dans l'étude de la dynamique de l'occupation du sol et des risques d'inondations à Yaoundé : cas du bassin versant du Mfoundi amont. Mémoire de DEA, Université de Yaoundé I, 119p. 